\title{
A 2-year record of atmospheric mercury species at a background Southern Hemisphere station on Amsterdam Island
}

\author{
H. Angot ${ }^{1}$, M. Barret ${ }^{1}$, O. Magand ${ }^{1}$, M. Ramonet ${ }^{2}$, and A. Dommergue ${ }^{1}$ \\ ${ }^{1}$ Univ. Grenoble Alpes/CNRS, Laboratoire de Glaciologie et Géophysique de l'Environnement (LGGE), \\ 38041 Grenoble, France \\ ${ }^{2}$ Laboratoire des Sciences du Climat et de l'Environnement (LSCE/IPSL), CEA-CNRS-UVSQ, \\ Gif-sur-Yvette,Cedex 91191, France
}

Correspondence to: H. Angot (helene.angot@lgge.obs.ujf-grenoble.fr)

Received: 20 May 2014 - Published in Atmos. Chem. Phys. Discuss.: 3 June 2014

Revised: 19 September 2014 - Accepted: 22 September 2014 - Published: 30 October 2014

\begin{abstract}
Although essential to fully understand the cycling of mercury at the global scale, mercury species records in the Southern Hemisphere are scarce. Under the framework of the Global Mercury Observation System (GMOS) project, a monitoring station has been set up on Amsterdam Island $\left(37^{\circ} 48^{\prime} \mathrm{S}, 77^{\circ} 34^{\prime} \mathrm{E}\right)$ in the remote southern Indian Ocean. For the first time in the Southern Hemisphere, a 2-year record of gaseous elemental mercury (GEM), reactive gaseous mercury (RGM) and particle-bound mercury (PBM) is presented. GEM concentrations were remarkably steady $\left(1.03 \pm 0.08 \mathrm{ng} \mathrm{m}^{-3}\right)$ while $\mathrm{RGM}$ and PBM concentrations were very low and exhibited a strong variability (mean: $0.34 \mathrm{pg} \mathrm{m}^{-3}$, range: < detection limit$4.07 \mathrm{pg} \mathrm{m}^{-3}$; and mean: $0.67 \mathrm{pg} \mathrm{m}^{-3}$, range: < detection limit-12.67 $\mathrm{pg} \mathrm{m}^{-3}$, respectively). Despite the remoteness of the island, wind sector analysis, air mass back trajectories and the observation of radonic storms highlighted a longrange contribution from the southern African continent to the GEM and PBM budgets from July to September during the biomass burning season. Low concentrations of GEM were associated with southerly polar and marine air masses from the remote southern Indian Ocean. This unique data set provides new baseline GEM concentrations in the Southern Hemisphere midlatitudes while mercury speciation along with upcoming wet deposition data will help to improve our understanding of the mercury cycle in the marine boundary layer.
\end{abstract}

\section{Introduction}

Due to its toxicity, persistence, bioaccumulative nature and long-range transport, mercury $(\mathrm{Hg})$ is a global threat to ecosystems and human health. Since the 1970s, multiple regulations have been implemented to tackle the exposure of populations to this contaminant. In 2013, the United Nations Environment Programme (UNEP) opened for signature a new legally binding treaty on mercury, giving birth to the Minamata Convention on mercury (UNEP, 2013). However, research gaps limiting mercury reduction policies at regional or global scale remain. For example, the policy effectiveness at reducing deposition of mercury requires a better knowledge of the chemistry of atmospheric mercury species (Selin, 2014).

According to recent estimates (Amos et al., 2013) while $10 \%$ of annual global emissions of atmospheric mercury currently come from natural geological sources - e.g., volcanic emissions or mercury-containing rocks $-30 \%$ are produced by a variety of anthropogenic activities - e.g., coal combustion, cement production, waste incineration or artisanal and small-scale gold mining - and reemissions of previously released mercury account for the remaining $60 \%$. Gaseous elemental mercury (GEM; $\mathrm{Hg}^{0}$ ) is the dominant form of atmospheric mercury (Lindberg and Stratton, 1998). It can be oxidized by ozone or free radicals into highly reactive and water-soluble divalent species $\left(\mathrm{Hg}^{2+}\right)$ and/or particle-bound mercury (PBM) (Lin and Pehkonen, 1999) that can be deposited through wet and dry processes (Lindqvist and Rodhe, 1985). 
In remote areas far from any local sources, atmospheric deposition has been recognized as the main source of mercury to the ocean (Lindberg et al., 2007). Mercury can then be reemitted back to the atmosphere via gas exchange (Schroeder and Munthe, 1998) and modeling studies suggest that reemission from oceans is a major contributor to atmospheric concentrations of GEM, particularly in the Southern Hemisphere where oceans were shown to contribute more than half of the surface atmospheric concentration (Strode et al., 2007). To better understand the cycling of mercury at the global scale a coordinated global monitoring network is needed (Pirrone et al., 2013), along with long-term records of atmospheric mercury species in the Southern Hemisphere and at background sites (Sprovieri et al., 2010). To date, observations in the Southern Hemisphere mainly rely on a few oceanographic campaigns (e.g., Lamborg et al., 1999; Temme et al., 2003a; Witt et al., 2010) and ongoing groundbased monitoring surveys at the Cape Point station in South Africa (Slemr et al., 2008) and at Troll, Dumont d'Urville and Concordia stations in Antarctica (Pfaffhuber et al., 2012; Dommergue et al., 2013a, b).

In this context, a monitoring station has been set up on Amsterdam Island, a remote island in the southern Indian Ocean, under the framework of the EuropeanUnion-financed project Global Mercury Observation System (GMOS; http://www.gmos.eu/). The 2-year record of elemental, divalent and particle-bound mercury concentrations presented here is, to the best of the authors' knowledge, the first reported in the Southern Hemisphere midlatitudes. Along with mercury species, ancillary parameters were analyzed to categorize air masses reaching the station based on their source region. The main objective of this study is to investigate to what extent observations at Amsterdam Island could define Southern Hemisphere midlatitude background conditions and provide new constraints in multiscale mercury species cycling models.

\section{Materials and methods}

\subsection{Sampling site description}

Amsterdam Island is a small island $\left(55 \mathrm{~km}^{2}\right)$ located in the southern Indian Ocean $\left(37^{\circ} 48^{\prime} \mathrm{S}, 77^{\circ} 34^{\prime} \mathrm{E}\right), 3400 \mathrm{~km}$ and $5000 \mathrm{~km}$ downwind from the nearest lands, Madagascar and South Africa, respectively (see Fig. 1). Instrumentation dedicated to the study of atmospheric mercury is located at the Pointe Bénédicte station, at the northwest end of the island, $55 \mathrm{~m}$ above sea level and $2 \mathrm{~km}$ west of the scientific base (30 residents at most). Other monitoring activities are performed at the station for various atmospheric compounds such as ozone (Gros et al., 1998), carbon monoxide (Gros et al., 1999), total aerosol number concentration (Sciare et al., 2001) or carbonaceous aerosol (Sciare et al., 2009).

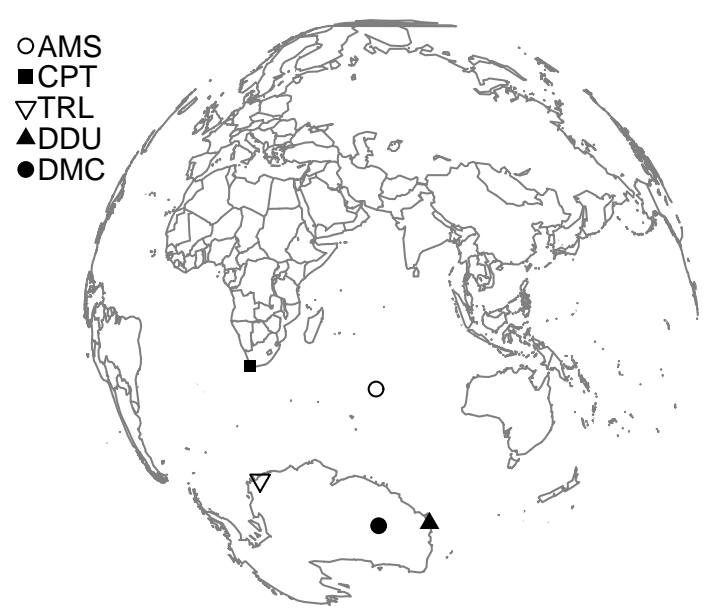

Figure 1. Location of Amsterdam Island (AMS), Cape Point (CPT), Troll (TRL), Dumont d'Urville (DDU), and Concordia (DMC) stations - projection centered over Amsterdam Island.

\subsection{Ancillary parameters}

Meteorological data - air temperature, relative humidity, barometric pressure, wind speed, and wind direction - were provided by the local meteorological station. Radon 222 and $220(\mathrm{Rn})$ are monitored with a precision of $10 \%$ on a $2 \mathrm{~h}$ basis. The method is described in detail by Polian et al. (1986) and Kritz et al. (1990). It is assumed that ${ }^{222} \mathrm{Rn}$ and ${ }^{220} \mathrm{Rn}$ are in radioactive equilibrium with their short-lived daughters so that ${ }^{222} \mathrm{Rn}$ and ${ }^{220} \mathrm{Rn}$ concentrations can be calculated by measuring the concentration of their short-lived decay products. Upon formation these short-lived daughters are quickly and irreversibly scavenged by aerosols and sampled by filtration. The detection then relies on the measurement over time of the decrease of alpha radioactivity of these aerosols.

$\mathrm{O}_{3}$ measurements have been performed at the Pointe Bénédicte station since 1994, halfway up on a $20 \mathrm{~m}$ high tower (Gros et al., 1998). Unfortunately, 2012 and 2013 data are not available due to technical problems.

A new cavity ring-down spectroscopy (CRDS) analyzer was installed at the Pointe Bénédicte station in 2012 for in situ measurements of $\mathrm{CH}_{4}$. This instrument (G2301, Picarro) is calibrated once a month with four reference gases (NO112004 scale for $\mathrm{CH}_{4}$ ).

7-days air mass back trajectories were calculated at $60 \mathrm{~m}$ above sea level, approximate sampling height for mercury analysis, using the HYSPLIT (HYbrid SingleParticle Lagrangian Integrated Trajectory) model accessed via the NOAA Air Resources Laboratory READY (Realtime Environmental Applications and Display sYstem) website (Draxler and Rolph, 2013; Rolph, 2013). Calculated back trajectories always have some uncertainty arising, for example, from the possible errors in input meteorological fields and the numerical methods (Yu et al., 2009), and increase with time along the way (Stohl, 1998). As suggested by Jaffe 
et al. (2005) it should be noted that back trajectories only give a general indication of the source region.

Fire counts and chlorophyll $a$ data west of Amsterdam Island were obtained via the FIRMS MODIS (Fire Information for Resource Management System, Moderate Resolution Imaging Spectroradiometer) Fire Archive Download (Davies et al., 2009) and the Giovanni online data system developed and maintained by the NASA GES DISC (Goddard Earth Sciences Data and Information Services Center), respectively.

\subsection{Mercury analyzers}

Since January 2012 we have monitored three atmospheric mercury species: GEM, PBM $(<2.5 \mu \mathrm{m})$ and reactive gaseous mercury (RGM), the latter consisting of various oxidized gaseous $\mathrm{Hg}^{2+}$ compounds and hereafter defined as all forms of mercury sampled using a $\mathrm{KCl}$-coated denuder (Landis et al., 2002).

Atmospheric mercury species measurements were performed using a Tekran mercury speciation unit (Tekran 1130 and 1135) coupled to a Tekran 2537B analyzer (Tekran Inc., Toronto, Canada). Concentrations are expressed in nanograms per cubic meter (GEM) or picograms per cubic meter (PBM and RGM), at standard temperature and pressure $(273.15 \mathrm{~K}, 1013.25 \mathrm{hPa})$. GEM was determined at subnanograms per cubic meter levels using a gas-phase mercury analyzer, based on the amalgamation of mercury onto a gold cartridge followed by a thermal desorption and detection by an integrated cold vapor atomic fluorescence spectrometer (CVAFS) at $253.7 \mathrm{~nm}$ (Fitzgerald and Gill, 1979; Bloom and Fitzgerald, 1988). The presence of two gold cartridges allowed alternating sampling and desorption modes and thus a continuous analysis of GEM in the sample air stream. In order to protect the two gold cartridges against deleterious compounds such as acid gases and halogen compounds, and against particulate matter, the sample air stream - after exiting the speciation unit - was prefiltered through a soda-lime trap and a $0.2 \mu \mathrm{m}$ PTFE (polytetrafluoroethylene) filter.

The speciation unit was located on the rooftop of the station, the sampling inlet being $6 \mathrm{~m}$ above the ground, and was connected to the $2537 \mathrm{~B}$ analyzer through a $10 \mathrm{~m}$ long PTFE heated line $\left(50^{\circ} \mathrm{C}\right)$. The sampling resolution was $5 \mathrm{~min}$ for GEM and $4 \mathrm{~h}$ for RGM and PBM, with sampling flow rates of $1 \mathrm{~L} \mathrm{~min}^{-1}$ and $10 \mathrm{~L} \mathrm{~min}^{-1}$, respectively. Measurements were achieved through a multistep procedure as described elsewhere (Lindberg et al., 2002) using an impactor inlet $(2.5 \mu \mathrm{m}$ cut-off aerodynamic diameter at $10 \mathrm{~L} \mathrm{~min}^{-1}$ ), a $\mathrm{KCl}$-coated quartz annular denuder in the 1130 unit, and a quartz regenerable particulate filter (RPF) in the 1135 unit.

\section{Quality assurance and quality control procedures}

Fortnightly to monthly routine maintenance operations on the denuder, RPF, soda-lime trap and filters, along with thor- ough cleaning steps and weekly site visits enabled collecting contamination-free air samples. The accuracy of flow measurements was checked twice a year with a calibrated flow meter (Definer 220). An automatic calibration step of the 2537B analyzer was carried out every $69 \mathrm{~h}$ with an internal mercury permeation source. The accuracy of this permeation source was annually checked against manual injections of saturated mercury vapor taken from a temperature-controlled vessel, using a Tekran 2505 mercury vapor calibration unit and a Hamilton digital syringe, and following a strict procedure adapted from Dumarey et al. (1985). Both routine and exceptional maintenance were compiled and archived via a software program developed at the LGGE (Laboratoire de Glaciologie et Géophysique de l'Environnement). This software program also enabled rapid data processing in order to produce clean time series of GEM, PBM and RGM. Screening criteria for data validation/invalidation were inspired by standard operative protocols used by the Canadian Atmospheric Mercury Measurement Network (CAMNet) and the Atmospheric Mercury Network (AMNet; Steffen et al., 2012). To ensure uniformity across the network, GMOS is currently developing a quality control (QC) software and an intercomparison with the AMNet QC software will be undertaken.

The best estimate of the detection limit (DL) for GEM measurements was $0.10 \mathrm{ng} \mathrm{m}^{-3}$ (Tekran, 2011) and 10 injections of $15 \mu \mathrm{L}$ of saturated mercury vapor were performed to check the repeatability of the system response. The system gave a relative expanded uncertainty of $1 \%$ (95\% confidence level). Validated 5 min GEM data subsets were compiled into hourly average data when the hourly recovery rate exceeded $50 \%$ (number of valid data records collected vs. that possible over the reporting period).

RGM and PBM sampling resolution was shifted from 3 to $4 \mathrm{~h}$ after a few days due to very low concentrations, and the detection limit therefore decreased from 0.42 to $0.28 \mathrm{pg} \mathrm{m}^{-3}$ based on the sampling volumes and GEM detection limit (Wang et al., 2014). The mean of the distributions was estimated using the Kaplan-Meier cumulative proportion-based method. It provides more reliable results for data sets containing below-detection limit values than the substitution method, i.e., replacement of below-detection limit values by a constant equal to 0, 0.5 DL or DL (Helsel, 2005). Overall, 75 and $50 \%$ of RGM and PBM measurements, respectively, were below the limits of detection resulting in differences for mean values of up to 60 and $15 \%$, respectively, comparing Kaplan-Meier and normally averaged data sets. Values 3.3 times above the stated detection limits, i.e., reliably quantified, will be discussed thereafter and referred to as RGM and PBM events ( 3 and $18 \%$ of RGM and PBM measurements, respectively).

There is growing evidence that RGM and PBM measurements might suffer from significant biases and interferences (Lyman et al., 2010; Gustin et al., 2013; Jaffe et al., 2014). Several studies highlighted the inefficient collection 


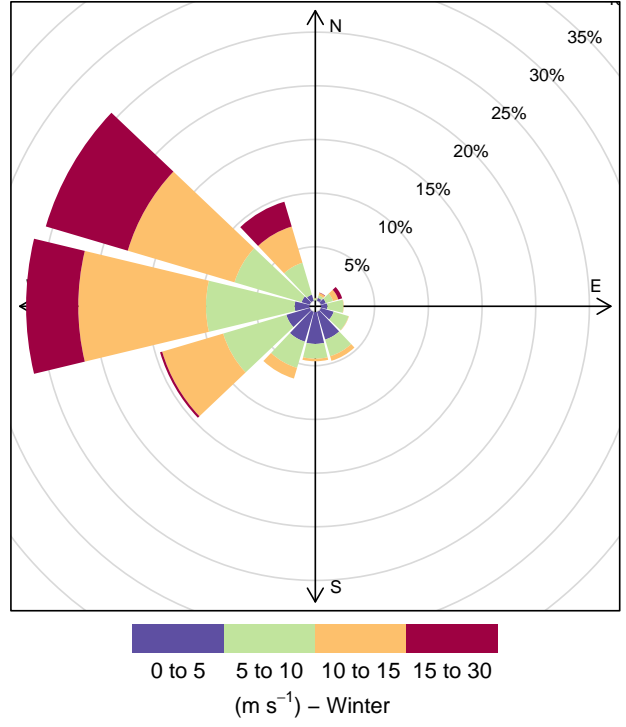

Frequency of counts by wind direction (\%)

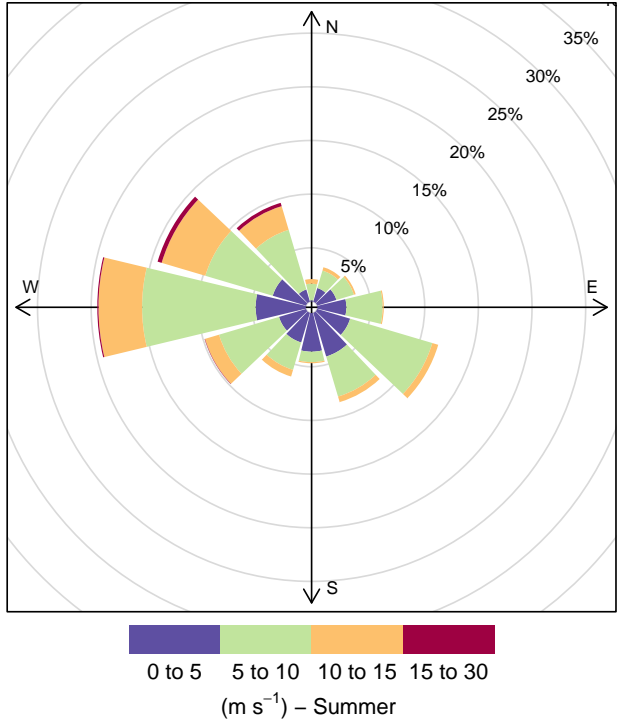

Frequency of counts by wind direction (\%)

Figure 2. Wind direction and wind speed $\left(\mathrm{m} . \mathrm{s}^{-1}\right)$ in winter (July-September) and summer (December-February) at the Pointe Bénédicte station. N: north, E: east, S: south, W: west.

of gaseous oxidized mercury compounds with a $\mathrm{KCl}$-coated denuder in the Tekran technique (Gustin et al., 2013; Huang et al., 2013), leading to an underestimation of reactive mercury concentrations by a factor of 1.3-3.7 (Huang et al., 2013). Other studies suggested sampling artifacts for PBM measurements due to temperature or sampling duration (Malcolm and Keeler, 2007; Rutter et al., 2008). Moreover, the upper size cutoff diameter at $2.5 \mu \mathrm{m}$ raises concerns about mercury associated with large $(>2.5 \mu \mathrm{m})$ particle fractions (Kos et al., 2013), especially in the marine environment where mercury is likely mainly contained in coarse sea salt aerosols (Talbot et al., 2011; Feddersen et al., 2012). There is no robust calibration technique of the Tekran speciation unit and no certified reference material available. The precision of RGM measurements - shown to be of $15 \%$ under given conditions (Landis et al., 2002) - should be assessed in various sampling environments (e.g., varying ozone/relative humidity conditions). Given the limitations of the RGM and PBM measurements, data reported in this study should thus only be directly compared with the existing Tekran-based literature, as suggested by Wang et al. (2014). An extensive data set has been gathered worldwide using the Tekran speciation technique, which is the best available automated method. Future interference and calibration tests are fundamental to validate measurements and quantify uncertainties (Kos et al., 2013), and might enable us to correct RGM and PBM data. Until then, orders of magnitude and variability in time and space of Tekran-based RGM and PBM concentrations can be used as first estimates by policy makers or to evaluate atmospheric models.

\section{Results and discussion}

\subsection{Meteorological data}

Climate is mild oceanic, with frequent presence of clouds. Seasonal boundaries were defined as follows: winter from July to September and summer from December to February, in line with other studies performed at Amsterdam Island (NGuyen et al., 1990; Gros et al., 1998; Sciare et al., 2009). During the 2-year period under discussion here (January 2012-December 2013), the monthly median air temperature ranged from $11^{\circ} \mathrm{C}$ in austral winter to $17^{\circ} \mathrm{C}$ in austral summer, while the monthly median relative humidity remained high and ranged from 65 to $85 \%$ most of the year. Precipitation was very frequent with total precipitation of $1262 \mathrm{~mm}$ in 2012 and $1128 \mathrm{~mm}$ in 2013, in good agreement with the $1124 \mathrm{~mm} 40$-year average reported by Miller et al. (1993). Wind speed remained comparatively high throughout the year (from 5 to $15 \mathrm{~m} \mathrm{~s}^{-1}$ ); strong northwesterly winds peaked during winter months (July-September) when the roaring forties were at a maximum (see Fig. 2).

\subsection{Gaseous elemental mercury concentrations}

\subsubsection{Seasonality and contribution from biomass burning}

GEM concentrations were very steady with an average hourly mean concentration of $1.03 \pm 0.08 \mathrm{ng} \mathrm{m}^{-3}$ (mean \pm standard deviation, range: $0.72-1.55 \mathrm{ng} \mathrm{m}^{-3}, n=10285$; see Fig. 3). GEM data are lower than concentrations reported in the Northern Hemisphere but well within the 


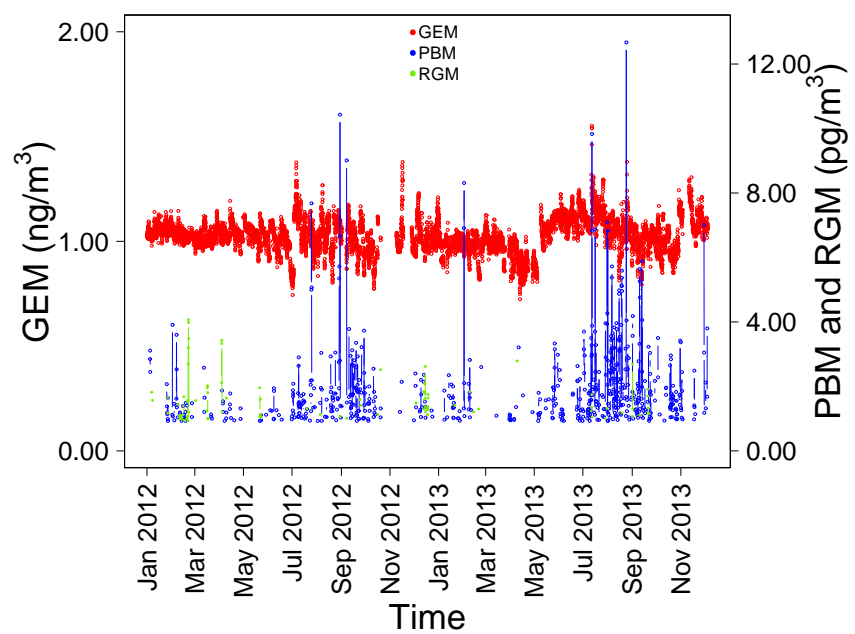

Figure 3. PBM (blue) and RGM (green) concentrations $\left(\mathrm{pg} \mathrm{m}^{-3}\right)$, and hourly average GEM (red) concentrations $\left(\mathrm{ng} \mathrm{m}^{-3}\right)$ measured at Amsterdam Island from January 2012 to December 2013.

expected range for a remote marine site in the Southern Hemisphere (Sprovieri et al., 2010). Indeed, Witt et al. (2010) measured a mean TGM (total gaseous mercury defined as the sum of gaseous mercury species) concentration of $1.24 \pm 0.06 \mathrm{ng} \mathrm{m}^{-3}$ in the Indian Ocean at latitudes ranging from 9 to $21^{\circ} \mathrm{S}$, while TGM concentrations ranged from 1.20 to $1.40 \mathrm{ng} \mathrm{m}^{-3}$ at the Cape Point station, South Africa $\left(34^{\circ} 21^{\prime} \mathrm{S}, 18^{\circ} 29^{\prime} \mathrm{E}\right)$, between 1995 and 2004 (Slemr et al., 2008) and GEM concentrations amounted to $0.93 \pm 0.19 \mathrm{ng} \mathrm{m}^{-3}$ at the Troll station in Antarctica (Pfaffhuber et al., 2012). GEM concentrations measured at Amsterdam Island are furthermore highly consistent with data reported by Wang et al. (2014) in the marine boundary layer over the Equator at the Galápagos Islands $\left(0^{\circ} 57^{\prime} \mathrm{S}\right.$, $90^{\circ} 58^{\prime} \mathrm{W} ; 1.08 \pm 0.17 \mathrm{ng} \mathrm{m}^{-3}$ ) despite occasional influence of northern hemispheric air at this station. A comprehensive comparison of mercury concentrations measured in the Southern Hemisphere is given in Slemr et al. (2014).

Whereas TGM and GEM concentrations at the Cape Point station and at Galápagos Islands, respectively, showed a seasonal variation (Slemr et al., 2008; Wang et al., 2014), with minimum in winter and maximum in summer, GEM data at Amsterdam Island followed an opposite trend, with slightly but significantly higher concentrations in winter (July-September) than in summer (December-February) $\left(1.06 \pm 0.09\right.$ vs. $1.04 \pm 0.07 \mathrm{ng} \mathrm{m}^{-3}, p$ value $<2.2 .10^{-16}$, Mann-Whitney test; see Fig. 4a).

This seasonality of GEM concentrations is in agreement with more frequent air masses originating from southern Africa (northwesterly winds) from July to September. In order to further test this hypothesis GEM data were sorted according to wind direction imposing a strict criterion on wind speed $\left(>8 \mathrm{~m} \mathrm{~s}^{-1}\right)$ to remove any local influence (Monfray et al., 1987). With north at $0^{\circ}$, southerly (S) winds ranged
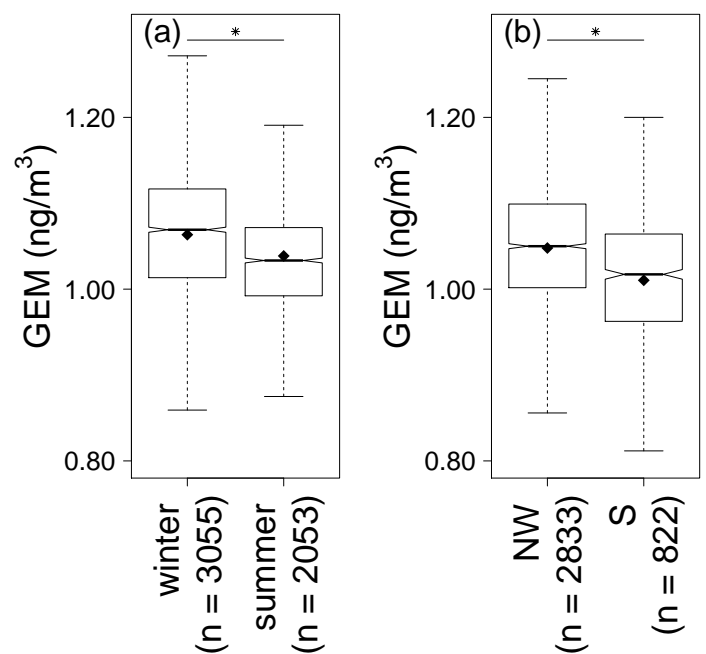

Figure 4. Hourly average GEM concentrations $\left(\mathrm{ng} \mathrm{m}^{-3}\right)$ measured at Amsterdam Island: (a) in winter (July-September) or summer (December-February) and (b) under NW or S winds. $\$$ : mean, $*$ : statistically significant difference, $n=$ number of hourly average data, bottom and top of the box: first and third quartiles, band inside the box: median, ends of the whiskers: lowest (highest) datum still within the 1.5 interquartile range of the lower (upper) quartile. Outliers are not represented

from 100 to $250^{\circ}$ and northwesterly (NW) winds from 250 to $300^{\circ}$. GEM concentrations monitored during periods of NW flow were shown to be significantly higher than during $\mathrm{S}$ flow $\left(1.05 \pm 0.08(n=2833)\right.$ vs. $1.01 \pm 0.08 \mathrm{ng} \mathrm{m}^{-3}(n=822), p$ value $<2.2 \cdot 10^{-16}$, Mann-Whitney test; see Fig. $4 \mathrm{~b}$ ).

The GEM budget on the island could be enhanced from July to September by long-range transport during the burning season in southern Africa. The 2012 and 2013 satellite observations of fires west of Amsterdam Island (latitude ranging from 3 to $53^{\circ} \mathrm{S}$ and longitude from 10 to $73^{\circ} \mathrm{E}$ ) showed that the burning season extended from May to October, peaking between June and September (see Fig. 5a), in line with observations reported by Cooke et al. (1996). This observation is also supported by the concomitant seasonal maxima on Amsterdam Island of CO (Gros et al., 1999), equivalent black carbon, non-sea-salt potassium and oxalate (Sciare et al., 2009), the latter two being commonly used as tracers for biomass burning.

\subsubsection{Short-time variations}

The atmosphere at Amsterdam Island could define background marine boundary layer conditions, with minimum perturbation from anthropogenic influences. However, as reported by Balkanski and Jacob (1990), the rapid export of air from southern Africa to the subantarctic Indian Ocean could constitute a major source of pollution to southern midlatitudes. The influence of continental air mass advection on GEM concentrations was thus investigated. 
The background variability of GEM concentrations was assessed following a procedure adapted from Gros et al. (1999) calculating the difference, dGEM, between hourly GEM concentrations and the monthly mean. dGEM events higher than $\pm 0.18 \mathrm{ng} \mathrm{m}^{-3}, 3$ times the mean monthly standard deviation of dGEM measurements, were further investigated.

${ }^{222} \mathrm{Rn}$, decay product of ${ }^{238} \mathrm{U}$ with a 3.8 day half-life, is particularly well suited as a tracer of continental air over the oceans (Balkanski and Jacob, 1990). However, ${ }^{220} \mathrm{Rn}$ and its daughter ${ }^{212} \mathrm{~Pb}$, due to $54 \mathrm{~s}$ and $10.6 \mathrm{~h}$ half-lives, respectively, can only be attributed to local outgassing from Amsterdam Island's soil and not to any marine nor remote continental source (Polian et al., 1986). Therefore, ${ }^{222} \mathrm{Rn}$ activities below $100 \mathrm{mBq} \mathrm{m}^{-3}$ are considered as typical for marine air (Brunke et al., 2004), whereas air with ${ }^{222} \mathrm{Rn}$ activity above $100 \mathrm{mBq} \mathrm{m}^{-3}$ along with a ${ }^{220} \mathrm{Rn}\left({ }^{212} \mathrm{~Pb}\right)$ activity below $3.7 \mathrm{mBq} \mathrm{m}^{-3}$ is considered to be significantly influenced by a remote continent (Gros et al., 1999; Williams et al., 2001). Rapid and sharp variations of ${ }^{222} \mathrm{Rn}$ activity, referred to as "radonic storms" (Lambert et al., 1970), could be observed at Amsterdam Island, usually peaking at around $400 \mathrm{mBq} \mathrm{m}^{-3}$ and exceptionally reaching $1000 \mathrm{mBq} \mathrm{m}^{-3}$. The occurrence of radonic storms was about 4\% in 2012 and $7 \%$ in 2013.

The local production of radon on Amsterdam Island can explain the radonic storm occurring on 13 December 2012 (see Fig. 6a). As reported by Polian et al. (1986), it is associated with low wind speeds (below $5 \mathrm{~m} \mathrm{~s}^{-1}$ ) and meteorological conditions corresponding to a low atmospheric eddy diffusion. The back trajectory ending on 13 December 2012 on Amsterdam Island (see Fig. 7) meanders over the ocean, and low south-eastern/eastern winds prevailed ahead of ${ }^{222} \mathrm{Rn}$ and ${ }^{220} \mathrm{Rn}$ peaks, in good agreement with an influence from the island and local radon exhausts. The associated highGEM event (dGEM $>0.18 \mathrm{ng} \mathrm{m}^{-3}$; see Fig. $6 \mathrm{~b}$ ) was significantly positively correlated with ${ }^{222} \mathrm{Rn}$ and ${ }^{220} \mathrm{Rn}$ activities $(r=0.83, p$ value $=0.005$ and $r=0.80, p$ value $=0.010$, respectively, Spearman test) and can therefore be attributed to a local non-anthropogenic source as no noteworthy activity occurred at the sampling station nor on the scientific base.

About $50 \%$ of sharp high-GEM events were associated with ${ }^{222} \mathrm{Rn}$ peaks, strong winds and ${ }^{220} \mathrm{Rn}$ activities below $3.7 \mathrm{mBq} \mathrm{m}^{-3}$, and therefore ascribed to continental air mass advection. For example, the high-GEM event on 21 September 2013 (see Fig. 6d) was associated with a ${ }^{222} \mathrm{Rn}$ peak of about $200 \mathrm{mBq} \mathrm{m}^{-3}$, a ${ }^{220} \mathrm{Rn}$ activity below $3.7 \mathrm{mBq} \mathrm{m}^{-3}$ and $15 \mathrm{~m} \mathrm{~s}^{-1}$ winds (see Fig. 6c). This high-GEM event was significantly positively correlated with ${ }^{222} \mathrm{Rn}$ activities but not correlated with ${ }^{220} \mathrm{Rn}$ activities $(r=0.81, p$ value $=9.3$ $10^{-5}$ and $r=-0.27, p$ value $=0.295$, respectively, Spearman test). The back trajectory ending on 21 September 2013 on Amsterdam Island (see Fig. 7) passes near the southern African continent and Madagascar, confirming the continental origin of the air at the time of enhanced ${ }^{222} \mathrm{Rn}$ activity and GEM concentrations. Although the back trajectory in-
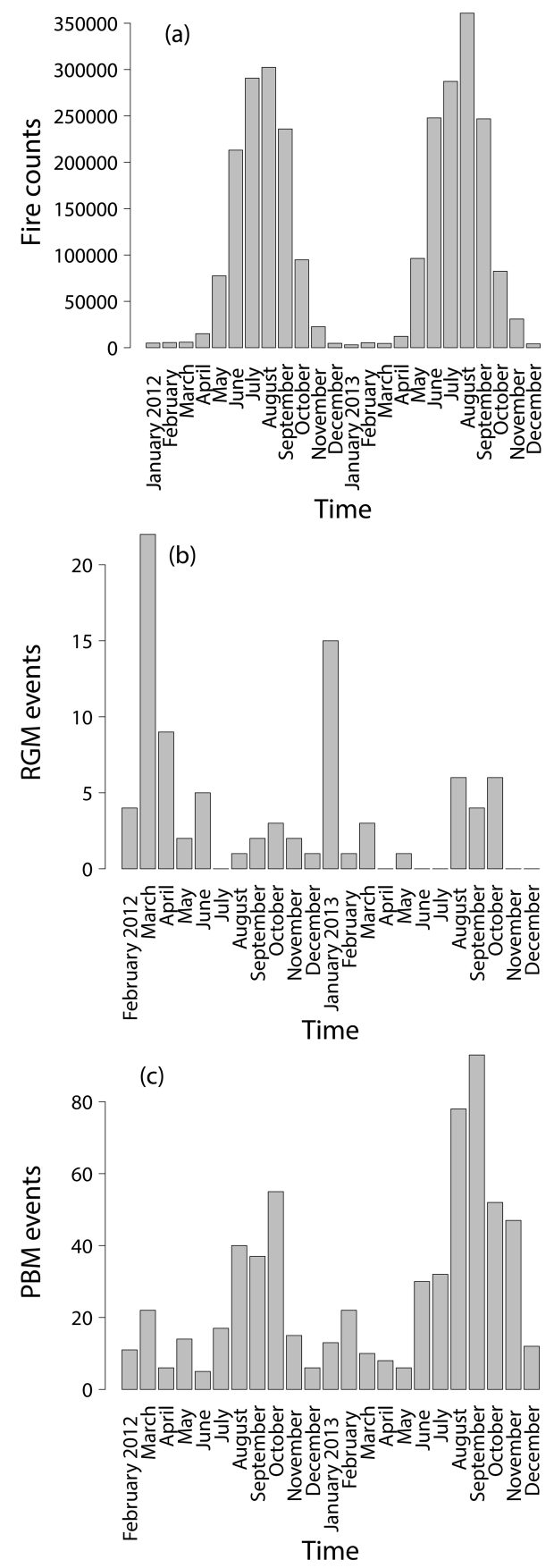

Figure 5. (a) Fire counts west of Amsterdam Island (latitude: 3$53^{\circ} \mathrm{S}$, longitude: $10-73^{\circ} \mathrm{E}$ ) in 2012 and 2013. Data courtesy of FIRMS MODIS Fire Archive Download. (b) RGM events, i.e., number of measurements above quantification limit, at Amsterdam Island from February 2012 to December 2013. (c) PBM events, i.e., number of measurements above quantification limit, at Amsterdam Island from February 2012 to December 2013.

dicates no direct passage over the continent, a continental origin of the air is not unlikely since that range of ${ }^{222} \mathrm{Rn}$ activities has already been measured for trajectories calculated 

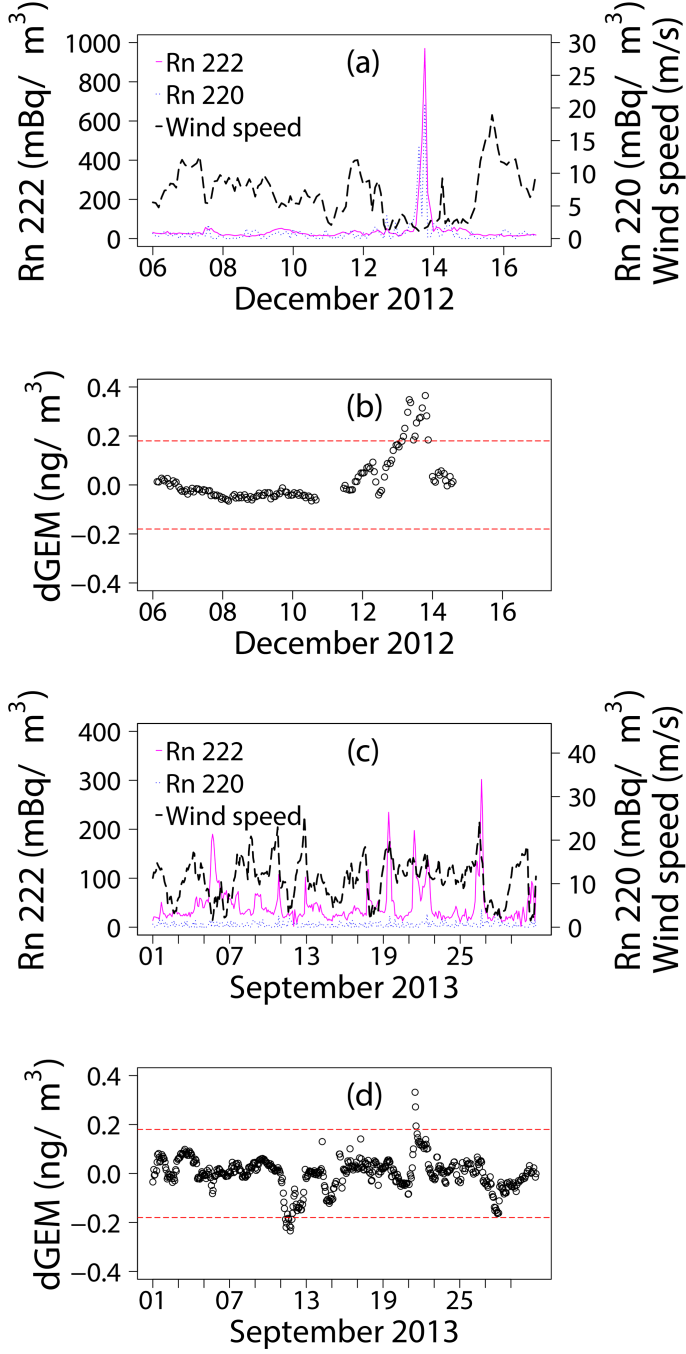

Figure 6. Examples of ${ }^{222} \mathrm{Rn}\left(\mathrm{mBq} \mathrm{m}^{-3}\right)$ peaks observed at Amsterdam Island along with ${ }^{220} \mathrm{Rn}\left(\mathrm{mBq} \mathrm{m}^{-3}\right)$ activity and wind speed $\left(\mathrm{m} \mathrm{s}^{-1}\right)$ (a) in December 2012 and (c) in September 2013. Background variability (dGEM; $\mathrm{ng} \mathrm{m}^{-3}$ ) of GEM concentrations observed at Amsterdam Island in (b) December 2012 and (d) September 2013. Dotted lines represent 3 times the mean monthly standard deviation of dGEM measurements.

to have passed more than $100 \mathrm{~km}$ away from mainland Australia (Whittlestone et al., 1998).

As for high-GEM events, continentally induced radonic storms mainly occurred between June and October reflecting the seasonality of wind direction at Amsterdam Island and of long-range transport from the southern African continent.

As illustrated in Figs. 6d and 7, low-GEM events (dGEM $<0.18 \mathrm{ng} \mathrm{m}^{-3}$ ) were well correlated with trajectories passing over Antarctica. This continent, almost entirely covered by ice, has low local emissions of ${ }^{222} \mathrm{Rn}$ and ${ }^{220} \mathrm{Rn}$ (Polian et al., 1986), explaining why low-GEM events are not associated with any ${ }^{222} \mathrm{Rn}$ peak.

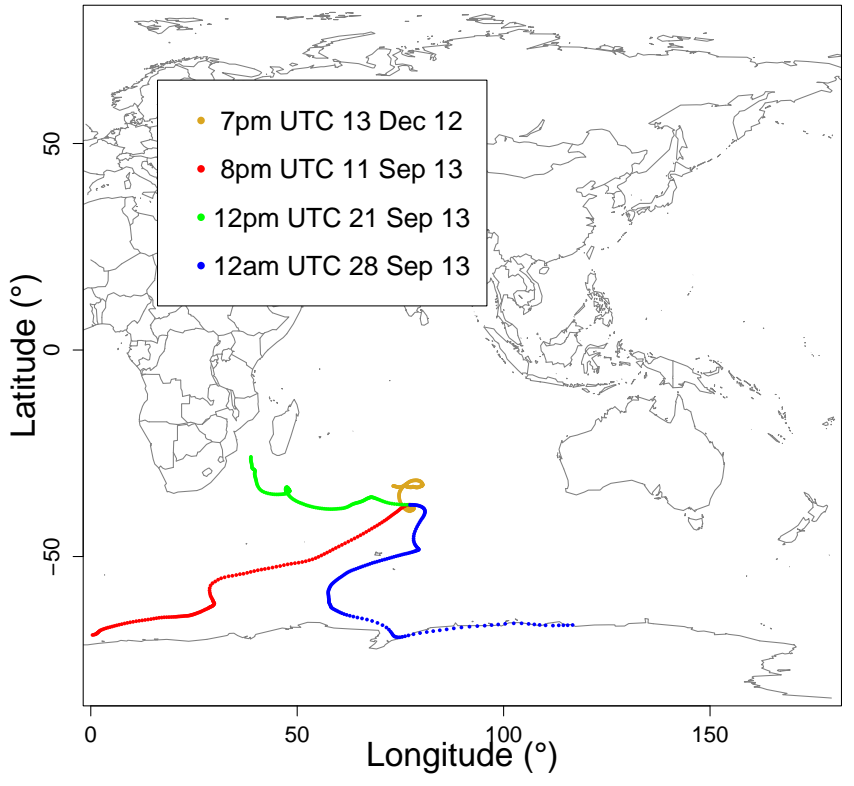

Figure 7. 7-days back trajectories ending on Amsterdam Island on 13 December 2012, 11 September 2013, 21 September 2013 and 28 September 2013. Data courtesy of NOAA.

These short-term variations suggest that cleaner air masses originate from the remote southern Indian Ocean while NW air masses are influenced by continental southern Africa, as previously assumed by several authors (Miller et al., 1993; Gros et al., 1999; Williams et al., 2001).

\subsubsection{Southern Hemisphere midlatitudes baseline concentrations for modeling studies}

The monthly means, medians and standard deviations are given in Table 1. Over 2 years the occurrence of high- and low-GEM events was less than $1 \%$ and these events did not significantly affect the monthly and annual means. Medians have been calculated for each month and differ in average from the arithmetical means by $0.90 \%$, which is less than the relative expanded uncertainty of the system response. The difference between mean and median did not show any seasonal variation.

GEM concentrations at Amsterdam Island can be considered as baseline concentrations and can be used as is in modeling studies. However, a slight but significant seasonal cycle was highlighted and despite the remoteness of the station an influence of biomass burning was observed from July to September. Biomass burning affects at least all of the Southern Hemisphere midlatitude belt and can be considered as widespread pollution (Fishman et al., 1991; Gros et al., 1999). Biomass burning slightly contributes to the background GEM level in this region and should be carefully considered in modeling studies when dealing with seasonality of GEM concentrations in the Southern Hemisphere midlatitudes. 


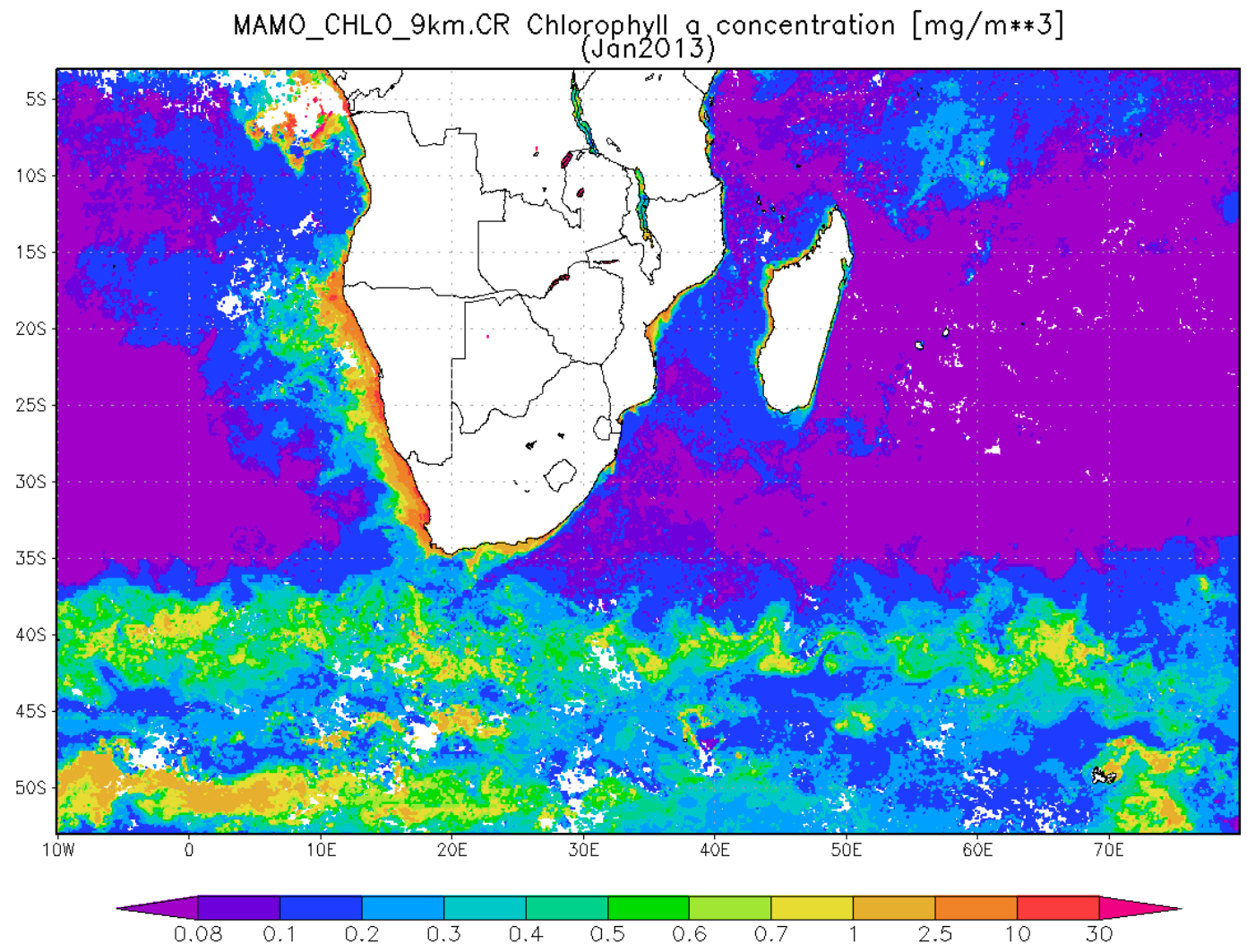

Figure 8. SeaWIFS chlorophyll $a$ map (January 2013) of the Indian sector of the Southern Ocean. The oceanic region located southwest of Amsterdam Island is highly productive in summer and potentially produces halogen species. Data courtesy of Giovanni online data system.

\subsection{Oxidized mercury species: seasonality and sources}

A 2-year record of RGM and PBM concentrations is presented hereafter - the longest ever reported in the Southern Hemisphere. Concentrations at Amsterdam Island were very low - at the lower end of the range reported during oceanographic campaigns (Laurier et al., 2003; Temme et al., 2003b; Laurier and Mason, 2007) - and exhibited a strong variability (see Fig. 3). RGM and PBM mean concentrations amounted to 0.34 (range: $<$ DL- $4.07 \mathrm{pg} \mathrm{m}^{-3}$ ) and $0.67 \mathrm{pg} \mathrm{m}^{-3}$ (range: $<$ DL-12.67 $\mathrm{pg} \mathrm{m}^{-3}$ ), respectively. Such low RGM and PBM concentrations at Amsterdam Island could be explained by the very frequent drizzle efficiently scavenging oxidized mercury species. To further investigate the latter assumption, a precipitation collector was set up on the island at the beginning of 2013 in order to analyze mercury species in rainwater.

\subsubsection{Reactive gaseous mercury}

RGM can be emitted from point sources or originate from oxidation of GEM. Due to its short lifetime RGM can only be transported tens to hundreds of kilometers in the boundary layer (Schroeder and Munthe, 1998). Monitoring of primary emitted RGM at Amsterdam Island is therefore unlikely.
RGM in the marine boundary layer has been reported to originate from a photochemically driven oxidation of GEM (Hedgecock and Pirrone, 2001; Hedgecock et al., 2003; Laurier et al., 2003) or through entrainment from the free troposphere (Holmes et al., 2009).

Oxidation pathways of GEM involving ozone $\left(\mathrm{O}_{3}\right)$, the hydroxyl radical $(\mathrm{OH})$, atomic bromine $(\mathrm{Br})$ or nitrogen dioxide $\left(\mathrm{NO}_{2}\right)$, or a combination of them, have been suggested by modeling and field studies (Holmes et al., 2010; Wang et al., 2014). Our understanding of RGM production mechanisms at Amsterdam Island is still limited and no anticorrelation between RGM and GEM concentrations, suggesting an insitu GEM oxidation, was found.

A slight but significant seasonal trend in RGM concentrations was highlighted $\left(1.34 \pm 0.45 \mathrm{pg} \mathrm{m}^{-3}\right.$ in winter (JulySeptember) vs. $1.58 \pm 0.35 \mathrm{pg} \mathrm{m}^{-3}$ in summer (DecemberFebruary), $p$ value $=0.01$, Mann-Whitney test), and RGM events occurred about $55 \%$ of the time between December and March (see Fig. 5b), in line with an enhanced photochemistry in summer. While a significant negative correlation between $\mathrm{CH}_{4}$ and air temperature was observed $\left(r=-0.638, p<2.210^{-16}\right.$, Spearman test), consistent with its photochemical destruction by the hydroxyl radical (Khalil and Rasmussen, 1983), no correlation was found between RGM concentrations and air temperature, or any other 
Table 1. Summary of monthly GEM data at Amsterdam Island.

\begin{tabular}{|c|c|c|c|c|c|}
\hline Month & $\begin{array}{r}\text { Mean } \\
\left(\mathrm{ng} \mathrm{m}^{-3}\right)\end{array}$ & $\begin{array}{r}\text { Median } \\
\left(\mathrm{ng} \mathrm{m}^{-3}\right)\end{array}$ & $\begin{array}{l}\text { Standard } \\
\text { deviation } \\
\left(\mathrm{ng} \mathrm{m}^{-3}\right)\end{array}$ & $\begin{array}{r}\text { Range } \\
\left(\mathrm{ng} \mathrm{m}^{-3}\right)\end{array}$ & $n$ \\
\hline \multicolumn{6}{|l|}{2012} \\
\hline January & 1.04 & 1.04 & 0.02 & $1.01-1.09$ & 60 \\
\hline February & 1.06 & 1.05 & 0.03 & $0.98-1.14$ & 457 \\
\hline March & 1.02 & 1.02 & 0.02 & $0.94-1.15$ & 459 \\
\hline April & 1.03 & 1.02 & 0.04 & $0.95-1.15$ & 474 \\
\hline May & 1.04 & 1.03 & 0.04 & $0.94-1.19$ & 468 \\
\hline June & 1.02 & 1.03 & 0.04 & $0.90-1.13$ & 451 \\
\hline July & 0.99 & 1.01 & 0.08 & $0.74-1.17$ & 519 \\
\hline August & 1.05 & 1.03 & 0.09 & $0.83-1.38$ & 501 \\
\hline September & 1.04 & 1.06 & 0.07 & $0.80-1.27$ & 442 \\
\hline October & 1.01 & 1.01 & 0.07 & $0.84-1.17$ & 416 \\
\hline November & 0.94 & 0.94 & 0.07 & $0.77-1.12$ & 184 \\
\hline December & 1.01 & 0.99 & 0.08 & $0.93-1.38$ & 255 \\
\hline \multicolumn{6}{|l|}{2013} \\
\hline January & 1.03 & 1.02 & 0.07 & $0.90-1.23$ & 474 \\
\hline February & 0.98 & 0.98 & 0.03 & $0.85-1.09$ & 417 \\
\hline March & 0.98 & 0.99 & 0.06 & $0.82-1.13$ & 457 \\
\hline April & 0.98 & 0.99 & 0.05 & $0.81-1.10$ & 385 \\
\hline May & 0.89 & 0.89 & 0.05 & $0.72-1.03$ & 437 \\
\hline June & 1.08 & 1.08 & 0.05 & $0.96-1.23$ & 414 \\
\hline July & 1.12 & 1.12 & 0.04 & $1.00-1.25$ & 551 \\
\hline August & 1.12 & 1.11 & 0.07 & $0.97-1.55$ & 534 \\
\hline September & 1.05 & 1.05 & 0.07 & $0.81-1.38$ & 508 \\
\hline October & 1.00 & 1.01 & 0.06 & $0.79-1.17$ & 515 \\
\hline November & 0.99 & 0.98 & 0.08 & $0.85-1.24$ & 516 \\
\hline December & 1.10 & 1.08 & 0.06 & $0.98-1.31$ & 390 \\
\hline
\end{tabular}

$n$ : number of measurements.

meteorological parameter. The lack of correlation between RGM concentrations and other parameters may come from the small number of RGM measurements above quantification limit $(n=87)$.

More frequent RGM events between December and March could also be in line with an enhanced biological activity in summer. The production of halogen species, photochemically oxidizing GEM, could be driven by biological activity (Gschwend et al., 1985). Unlike the oceanic region surrounding Amsterdam Island, an area located in a southwest upwind sector covering the subtropical front (see Fig. 8) is highly productive, with a marine productivity (characterized by chlorophyll $a$ concentration) peaking from December to January and sometimes in March-April (Sciare et al., 2009), in agreement with peaks of RGM events. Similarly, marine organic aerosol concentrations at Amsterdam Island have been shown to be directly related to the seasonal cycle of chlorophyll $a$ (Sciare et al., 2009) and dimethyl sulfide (DMS) concentrations peaking in summer have been reported on the island, in line with an enhanced biological activity (NGuyen et al., 1990; Sciare et al., 1999).

While enhanced photochemistry and biological activity in summer might explain more frequent RGM events at Am-

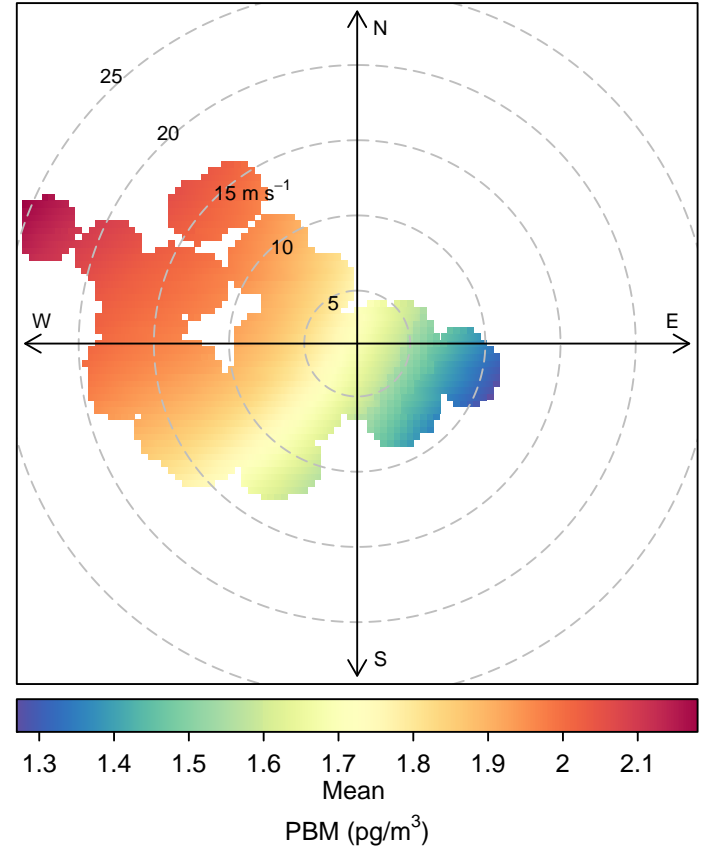

Figure 9. PBM concentrations $\left(\mathrm{pg} \mathrm{m}^{-3}\right)$ according to wind speed $\left(\mathrm{m} \mathrm{s}^{-1}\right)$ and direction.

sterdam Island between December and March, further field studies are needed to fully understand divalent mercury formation pathways.

\subsubsection{Particle-bound mercury}

PBM is associated with airborne particles - e.g., dust, soot, sea-salt aerosols or ice crystals - or originates from the adsorption of reactive mercury onto atmospheric particles $(\mathrm{Lu}$ and Schroeder, 2004). Field and modeling studies (Rutter and Schauer, 2007; Amos et al., 2012; Steffen et al., 2014) suggested that the partitioning of mercury onto particles might be driven by air temperature and aerosol particle loadings.

PBM concentrations at Amsterdam Island followed a seasonal trend with significantly higher concentrations in winter (July-September) than in summer (DecemberFebruary) $\left(2.18 \pm 1.56 \mathrm{ng} \mathrm{m}^{-3}\right.$ vs. $1.79 \pm 1.15 \mathrm{pg} \mathrm{m}^{-3}, p$ value $=0.027$, Mann-Whitney test). Higher PBM concentrations were recorded during the strongest $\mathrm{NW}$ winds episodes (see Fig. 9), suggesting an enhanced long-range transport of PBM from continental southern Africa during strong NW winds episodes. The higher number of PBM events in 2013 (see Fig. 5c) is in good agreement with about twice as many continentally induced radonic storms observed at Amsterdam Island in 2013 than in 2012.

PBM events occurred about $55 \%$ of the time between August and October in 2012 and 2013 (see Fig. 5c) and were significantly positively correlated with fire counts west of Amsterdam Island $(r=0.56, p$ value $=0.005$, Spearman test). This result is consistent with other observations of 
enhanced PBM concentrations during wildfires (Finley et al., 2009). However, biomass fire counts reached a maximum between June and September while PBM events peaked later, between August and October. The seasonality of aerosol optical depth (AOD) in the Southern Hemisphere Africa biomass burning region was extensively monitored by the Cimel sun-sky radiometer at the AERONET (Aerosol Robotic Network) site in Mongu, Zambia. Measurements from 1995 to 2009 highlighted that the monthly means of level 2 direct sun-measured 500 nm AOD at Mongu reached a peak from August to October (Eck et al., 2013), in line with the PBM events peak observed at Amsterdam Island. This time lag between seasonal peaks in fire counts and emissions has already been pointed out by Swap et al. (2003), but its origin remains unclear. It has been attributed either to unusual synoptic conditions favoring eastward transport of pollution over measurement sites (Stein et al., 2003; Swap et al., 2003) or to undetected/highly emissive densely wooded vegetation burns at the end of the fire season (Edwards et al., 2006).

\section{Conclusions}

Wind sector analysis, air mass back trajectories and the observation of radonic storms led to the important conclusion that despite the remoteness of Amsterdam Island, the rapid export of air from the southern African continent during the biomass burning season contributes to GEM and PBM budgets on the island. Low-GEM concentrations are associated with southerly polar and marine air masses from the remote southern Indian Ocean. This data set provides a new insight into baseline concentrations of mercury species in the Southern Hemisphere midlatitudes and new measurement constraints on the mercury cycle, opening the way for new avenues in future modeling studies. Our understanding of the mercury cycle in the marine boundary layer over Amsterdam Island is still limited. It represents a real challenge given harsh weather conditions - with a very frequent drizzle most certainly scavenging oxidized species - and technical and logistical limitations. Further studies involving wet deposition, simultaneous measurements of other trace gases, and interference and calibration tests of the Tekran speciation unit are needed to improve our understanding of deposition processes and oxidation mechanisms.

Acknowledgements. This work contributes to the EU-FP7 project Global Mercury Observation System (GMOS). Logistical and financial support was provided by the French Polar Institute IPEV (Program 1028, GMOStral). Financial support was also provided by a grant from Labex OSUG@2020 (ANR10 LABX56) and LEFE CNRS/INSU (program SAMOA). We deeply thank the overwintering staff: B. Brouillard, J. Chastain, E. Coz, A. Croguennoc, M. Le Dréau and V. Lucaire. A. Dommergue acknowledges the Institut Universitaire de France. We also gratefully acknowledge the MODIS mission scientists and associated NASA personnel for the production of the data used in this research effort, and the NOAA Air Resources Laboratory (ARL) for the provision of the READY website (http://www.ready.noaa.gov) used in this publication.

Edited by: R. Ebinghaus

\section{References}

Amos, H. M., Jacob, D. J., Holmes, C. D., Fisher, J. A., Wang, Q., Yantosca, R. M., Corbitt, E. S., Galarneau, E., Rutter, A. P., Gustin, M. S., Steffen, A., Schauer, J. J., Graydon, J. A., Louis, V. L. St., Talbot, R. W., Edgerton, E. S., Zhang, Y., and Sunderland, E. M.: Gas-particle partitioning of atmospheric $\mathrm{Hg}(\mathrm{II})$ and its effect on global mercury deposition, Atmos. Chem. Phys., 12, 591-603, doi:10.5194/acp-12-591-2012, 2012.

Amos, H. M., Jacob, D. J., Streets, D. G., and Sunderland, E. M.: Legacy impacts of all-time anthropogenic emissions on the global mercury cycle, Global Biogeochem. Cy., 27, 1-12, 2013.

Balkanski, Y. J., and Jacob, D. J.: Transport of continental air to the subantarctic indian ocean, Tellus, 42B, 62-75, 1990.

Bloom, N. S. and Fitzgerald, W. F.: Determination of volatile mercury species at the picogram level by low temperature gas chromatography with cold-vapor atomic fluorescence detection, Anal. Chim. Acta, 208, 151-161, 1988.

Brunke, E.-G., Labuschagne, C., Parker, B., Scheel, H. E., and Whittlestone, S.: Baseline air mass selection at Cape Point, South Africa: application of ${ }^{222} \mathrm{Rn}$ and other filter criteria to $\mathrm{CO}_{2}$, Atmos. Environ., 38, 5693-5702, 2004.

Cooke, W. F., Koffi, B., and Grégoire, J.-M.: Seasonality of vegetation fires in Africa from remote sensing data and application to a global chemistry model, J. Geophys. Res., 101, 21051-21065, 1996.

Davies, D. K., Ilavajhala, S., Wong, M. M., and Justice, C. O.: Fire information for resource management system: archiving and distributing MODIS active fire data, IEEE Trans. Geosci. Remote Sens., 47, 72-79, 2009.

Dommergue, A., Ferrari, C. P., Magand, O., Barret, M., Gratz, L. E., Pirrone, N., and Sprovieri, F.: Monitoring of gaseous elemental mercury in central Antarctica at Dome Concordia, E3S Web of Conferences, Proceedings of the 16th international conference on heavy metals in the environment, 23-27 September 2012, Rome, Italy, 1, 17003, doi:10.1051/e3sconf/20130117003, 2013a.

Dommergue, A., Vogel, N., Ferrari, C. P., Magand, O., and Barret, M.: Preliminary results from a continuous record of atmospheric gaseous mercury at the coastal station Dumont d'Urville in Antarctica, E3S Web of Conferences. Proceedings of the 16th international conference on heavy metals in the environment, 23-27 September 2012, Rome, Italy, 1, 27005, doi:10.1051/e3sconf/20130127005, 2013b.

Draxler, R. R. and Rolph, G. D.: HYSPLIT (HYbrid Single-Particle Lagrangian Integrated Trajectory) Model access via NOAA ARL READY Website, available at: http://www.arl.noaa.gov/ HYSPLIT.php (last access: 24 February 2014), NOAA Air Resources Laboratory, College Park, MD, 2013.

Dumarey, R., Temmerman, E., Dams, R., and Hoste, J.: The accuracy of the vapour injection calibration method for the determina- 
tion of mercury by amalgamation/cold vapour atomic spectrometry, Anal. Chim. Acta, 170, 337-340, 1985.

Eck, T. F., Holben, B. N., Reid, J. S., Mukelabai, M. M., Piketh, S. J., Torres, O., Jethva, H. T., Hyer, E. J., Ward, D. E., Dubovik, O., Sinyuk, A., Schafer, J. S., Giles, D. M., Sorokin, M., Smirnov, A., and Slutsker, I.: A seasonal trend of single scattering albedo in southern African biomass-burning particles: implications for satellite products biomass-burning sources, J. Geophys. Res., 118, 6414-6432, 2013.

Edwards, D. P., Emmons, L. K., Gille, J. C., Chu, A., Attié, J.-L., Giglio, L., Wood, S. W., Haywood, J., Deeter, M. N., Massie, S. T., Ziskin, D. C., and Drummond, J. R.: Satellite-observed pollution from southern hemisphere biomass burning, J. Geophys. Res., 111, 1-17, 2006.

Feddersen, D. M., Talbot, R., Mao, H., and Sive, B. C.: Size distribution of particulate mercury in marine and coastal atmospheres, Atmos. Chem. Phys., 12, 10899-10909, doi:10.5194/acp-1210899-2012, 2012.

Finley, B. D., Swartzendruber, P. C., and Jaffe, D. A.: Particulate mercury emissions in regional wildfire plumes observed at the mount bachelor observatory, Atmos. Environ., 43, 6074-6083, 2009.

Fishman, J., Fakhruzzaman, K., Cros, B., and Nganga, D.: Identification of widespread pollution in the southern hemisphere deduced from satellite analyses, Science, 252, 1693-1696, 1991.

Fitzgerald, W. F. and Gill, G. A.: Subnanogram determination of mercury by two-stage gold amalgamation and gas detection applied to atmospheric analysis, Anal. Chem., 51, 1714-1720, 1979.

Gros, V., Poisson, N., Martin, D., Kanakidou, M., and Bonsang, B.: Observations and modeling of the seasonal variation of surface ozone at Amsterdam Island: 1994-1996, J. Geophys. Res., 103, 103-109, 1998.

Gros, V., Bonsang, B., Martin, D., and Novelli, P. C.: Carbon monoxide short term measurements at Amsterdam Island: estimation of biomass burning rates, Chemosphere Global Change Sci., 1, 163-172, 1999.

Gschwend, P. M., Macfarlane, J. K., and Newman, K. A.: Volatile halogenated organic compounds released to seawater from temperate marine macroalgae, Science, 227, 1033-1035, 1985.

Gustin, M. S., Huang, J., Miller, M. B., Peterson, C., Jaffe, D. A., Ambrose, J., Finley, B. D., Lyman, S. N., Call, K., Talbot, R., Feddersen, D., Mao, H., and Lindberg, S. E.: Do we understand what the mercury speciation instruments are actually measuring? Results of RAMIX, Environ. Sci. Technol., 47, 7295-7306, 2013.

Hedgecock, I. M. and Pirrone, N.: Mercury and photochemistry in the marine boundary layer-modelling studies suggest the in situ production of reactive gas phase mercury, Atmos. Environ., 35, 3055-3062, 2001.

Hedgecock, I. M., Pirrone, N., Sprovieri, F., and Pesenti, E.: Reactive gaseous mercury in the marine boundary layer: modelling and experimental evidence of its formation in the mediterranean region, Atmos. Environ., 37, S41-S49, 2003.

Helsel, D. R.: More than obvious: Better methods for interpreting nondetect data, Environ. Sci. Technol., 39, 419A-423A, 2005.

Holmes, C. D., Jacob, D. J., Mason, R. P., and Jaffe, D. A.: Sources and deposition of reactive gaseous mercury in the marine atmosphere, Atmos. Environ., 43, 2278-2285, 2009.
Holmes, C. D., Jacob, D. J., Corbitt, E. S., Mao, J., Yang, X., Talbot, R., and Slemr, F.: Global atmospheric model for mercury including oxidation by bromine atoms, Atmos. Chem. Phys., 10, 12037-12057, doi:10.5194/acp-10-12037-2010, 2010.

Huang, J., Miller, M. B., Weiss-Penzias, P., and Gustin, M. S.: Comparison of gaseous oxidized mercury measured by $\mathrm{KCl}$-coated denuders, and nylon and cation exchange membranes, Environ. Sci. Technol., 47, 7307-7316, 2013.

Jaffe, D. A., Prestbo, E., Swartzendruber, P., Weiss-Penzias, P., Kato, S., Takami, A., Hatakeyama, S., and Kajii, Y.: Export of atmospheric mercury from Asia, Atmos. Environ., 2005, 3029 3038, 2005.

Jaffe, D. A., Lyman, S., Amos, H. M., Gustin, M. S., Huang, J., Selin, N. E., Levin, L., Schure, A., Mason, R. P., Talbot, R., Rutter, A. P., Finley, B., Jaeglé, L., Shah, V., McClure, C., Ambrose, J., Gratz, L., Lindberg, S. E., Weiss-Penzias, P., Sheu, G.-R., Feddersen, D., Horvat, M., Dastoor, A., Hynes, A. J., Mao, H., Sonke, J. E., Slemr, F., Fisher, J. A., Ebinghaus, R., Zhang, B., and Edwards, D. P.: Progress on understanding atmospheric mercury hampered by uncertain measurements, Environ. Sci. Technol., 48, 7204-7206, 2014.

Khalil, M. A. K. and Rasmussen, R. A.: Sources, sinks, and seasonal cycles of atmospheric methane, J. Geophys. Res., 88, 51315144, 1983.

Kos, G., Ryzhkov, A., Dastoor, A., Narayan, J., Steffen, A., Ariya, P. A., and Zhang, L.: Evaluation of discrepancy between measured and modelled oxidized mercury species, Atmos. Chem. Phys., 13, 4839-4863, doi:10.5194/acp-13-4839-2013, 2013.

Kritz, M. A., Le Roulley, J.-C., and Danielsen, E. F.: The China Clipper - fast advective transport of radon-rich air from the Asian boundary layer to the upper troposphere near California, Tellus B, 42, 46-61, 1990.

Lambert, G., Polian, G., and Taupin, D.: Existence of periodicity in radon concentrations and in the large-scale circulation at latitudes between $40^{\circ}$ and $70^{\circ} \mathrm{S}$, J. Geophys. Res., 75, 2341-2345, 1970.

Lamborg, C. H., Rolfhus, K. R., Fitzgerald, W. F., and Kim, G.: The atmospheric cycling and air-sea exchange of mercury species in the south and equatorial atlantic ocean, Deep-Sea Res. II, 46, 957-977, 1999.

Landis, M. S., Stevens, R. K., Schaedlich, F., and Prestbo, E. M.: Development and characterization of an annular denuder methodology for the measurement of divalent inorganic reactive gaseous mercury in ambient air, Environ. Sci. Technol., 36, 3000-3009, 2002.

Laurier, F. and Mason, R. P.: Mercury concentration and speciation in the coastal and open ocean boundary layer, J. Geophys. Res. 112, D06302, doi:10.1029/2006JD007320, 2007.

Laurier, F., Mason, R. P., Whalin, L., and Kato, S.: Reactive gaseous mercury formation in the north pacific ocean's marine boundary layer: a potential role of halogen chemistry, J. Geophys. Res., 108, 4529, doi:10.1029/2003JD003625, 2003.

Lin, C.-J. and Pehkonen, S. O.: The chemistry of atmospheric mercury: a review, Atmos. Environ., 33, 2067-2079, 1999.

Lindberg, S. E. and Stratton, W. J.: Atmospheric mercury speciation: concentrations and behavior of reactive gaseous mercury in ambient air, Environ. Sci. Technol., 32, 49-57, 1998.

Lindberg, S. E., Brooks, S., Lin, C.-J., Scott, K. J., Landis, M. S., Stevens, R. K., Goodsite, M. E., and Richter, A.: Dynamic oxida- 
tion of gaseous mercury in the arctic troposphere at polar sunrise, Environ. Sci. Technol., 36, 1245-1256, 2002.

Lindberg, S. E., Bullock, R., Ebinghaus, R., Engstrom, D., Feng, X., Fitzgerald, W. F., Pirrone, N., Prestbo, E., and Seigneur, C.: A synthesis of progress and uncertainties in attributing the sources of mercury in deposition, Ambio, 36, 19-32, 2007.

Lindqvist, O. and Rodhe, H.: Atmospheric mercury - a review, Tellus B, 37, 136-159, 1985.

Lu, J. Y. and Schroeder, W. H.: Annual time-series of total filterable atmospheric mercury concentrations in the Arctic, Tellus B, 56, 213-222, 2004.

Lyman, S. N., Jaffe, D. A., and Gustin, M. S.: Release of mercury halides from $\mathrm{KCl}$ denuders in the presence of ozone, Atmos. Chem. Phys., 10, 8197-8204, doi:10.5194/acp-10-81972010, 2010.

Malcolm, E. G. and Keeler, G. J.: Evidence for a sampling artifact for particulate-phase mercury in the marine atmosphere, Atmos. Environ., 41, 3352-3359, 2007.

Miller, J. M., Moody, J. L., Harris, J. M., and Gaudry, A.: A 10-year trajectory flow climatology for Amsterdam island, 1980-1989, Atmos. Environ., 27, 1909-1916, 1993.

Monfray, P., Gaudry, A., Polian, G., and Lambert, G.: Seasonal variations of atmospheric $\mathrm{CO}_{2}$ in the southern Indian Ocean, Tellus B, 39, 67-71, 1987.

NGuyen, B. C., Mihalopoulos, N., and Belviso, S.: Seasonal variation of atmospheric dimethylsulfide at Amsterdam Island in the southern Indian Ocean, J. Atmos. Chem., 11, 123-141, 1990.

Pfaffhuber, K. A., Berg, T., Hirdman, D., and Stohl, A.: Atmospheric mercury observations from Antarctica: seasonal variation and source and sink region calculations, Atmos. Chem. Phys., 12, 3241-3251, doi:10.5194/acp-12-3241-2012, 2012.

Pirrone, N., Aas, W., Cinnirella, S., Ebinghaus, R., Hedgecock, I. M., Pacyna, J. M., Sprovieri, F., and Sunderland, E. M.: Toward the next generation of air quality monitoring: mercury, Atmos. Environ., 80, 599-611, 2013.

Polian, G., Lambert, G., Ardouin, B., and Jegou, A.: Long range transport of continental radon in subantarctic and antarctic areas, Tellus, Ser. B, 38, 178-189, 1986.

Rolph, G. D.: Real-time Environmental Applications and Display sYstem (READY) Website, available at: http://www.ready.noaa. gov (last access: 24 February 2014), NOAA Air Resources Laboratory, College Park, MD, 2013.

Rutter, A. P. and Schauer, J. J.: The effect of temperature on the gasparticle partitioning of reactive mercury in atmospheric aerosols, Atmos. Environ., 41, 8647-8657, 2007.

Rutter, A. P., Hanford, K. L., Zwers, J. T., and Perillo-Nicholas, A. L.: Evaluation of an offline method for the analysis of atmospheric reactive gaseous mercury and particulate mercury, J. Air Waste Manag. Assoc., 58, 377-383, 2008.

Schroeder, W. H. and Munthe, J.: Atmospheric mercury - an overview, Atmos. Environ., 32, 809-822, 1998.

Sciare, J., Mihalopoulos, N., and NGuyen, B. C.: Summertime seawater concentrations of dimethylsulfide in the western indian ocean: reconciliation of fluxes and spatial variability with longterm atmospheric observations, J. Atmos. Chem., 32, 357-373, 1999.

Sciare, J., Mihalopoulos, N., and Baboukas, E.: Short-term variations of dimethylsulfide and its oxidation products at Amsterdam Island during summer time, J. Atmos. Chem., 39, 281-302, 2001.
Sciare, J., Favez, O., Sarda-Estève, R., Oikonomou, K., Cachier, H., and Kazan, V.: Long-term observations of carbonaceous aerosols in the austral ocean atmosphere: evidence of a biogenic marine organic source, J. Geophys. Res., 114, D15302, doi:10.1029/2009JD011998, 2009.

Selin, N. E.: Global change and mercury cycling: challenged for implementing a global mercury treaty, Environ. Toxicol. Chem., 33, 1202-1210, 2014.

Slemr, F., Brunke, E.-G., Labuschagne, C., and Ebinghaus, R.: Total gaseous mercury concentrations at the Cape Point GAW station and their seasonality, Geophys. Res. Lett., 35, L11807, doi:10.1029/2008GL033741, 2008.

Slemr, F., Angot, H., Dommergue, A., Magand, O., Barret, M., Weigelt, A., Ebinghaus, R., Brunke, E.-G., Pfaffhuber, K. A., Edwards, G., Howard, D., Powell, J., Keywood, M., and Wang, F.: Comparison of mercury concentrations measured at several sites in Southern Hemisphere, submitted to Atmos. Chem. Phys., 2014.

Sprovieri, F., Pirrone, N., Ebinghaus, R., Kock, H., and Dommergue, A.: A review of worldwide atmospheric mercury measurements, Atmos. Chem. Phys., 10, 8245-8265, doi:10.5194/acp10-8245-2010, 2010.

Steffen, A., Scherz, T., Oslon, M., Gay, D. A., and Blanchard, P.: A comparison of data quality control protocols for atmospheric mercury speciation measurements, J. Environ. Monit., 14, 752765, 2012.

Steffen, A., Bottenheim, J., Cole, A., Ebinghaus, R., Lawson, G., and Leaitch, W. R.: Atmospheric mercury speciation and mercury in snow over time at Alert, Canada, Atmos. Chem. Phys., 14, 2219-2231, doi:10.5194/acp-14-2219-2014, 2014.

Stein, D. C., Swap, R. J., Greco, S., Piketh, S. J., Macko, S. A., Doddridge, B. G., Elias, T., and Bruintjes, R. T.: Haze layer characterization and associated meteorological controls along the eastern coastal region of southern africa, J. Geophys. Res., 108, 8506, doi:10.1029/2002JD003237, 2003.

Stohl, A.: Computation, accuracy and application of trajectories - a review and bibliography, Atmos. Environ., 32, 947-966, 1998.

Strode, S. A., Jaeglé, L., Selin, N. E., Jacob, D. J., Park, R. J., Yantosca, R. M., Mason, R. P., and Slemr, F.: Air-sea exchange in the glocal mercury cycle, Global Biogeochem. Cy., 21, GB1017, doi:10.1029/2006GB002766, 2007.

Swap, R. J., Annegarn, H. J., Suttles, J. T., King, M. D., Platnick, S., Privette, J. L., and Scholes, R. J.: Africa burning: a thematic analysis of the southern african regional science initiative (SAFARI 2000), J. Geophys. Res., 108, 8465, doi:10.1029/2003JD003747, 2003.

Talbot, R., Mao, H., Feddersen, D., Smith, M., Kim, S. Y., Sive, B. C., Haase, K., Ambrose, J., Zhou, Y., and Russo, R.: Comparison of particulate mercury measured with manual and automated methods, Atmosphere, 2, 1-20, 2011.

Tekran: Tekran 2537 mercury monitor detection limit. Summary of known estimates, Tekran Instruments Corp., Toronto, ON, Canada, 2011.

Temme, C., Slemr, F., Ebinghaus, R., and Einax, J. W.: Distribution of mercury over the atlantic ocean in 1996 and 1999-2001, Atmos. Environ., 37, 1889-1897, 2003a.

Temme, C., Einax, J. W., Ebinghaus, R., and Schroeder, W. H.: Measurements of atmospheric mercury species at a coastal site 
in the antarctic and over the atlantic ocean during polar summer, Environ. Sci. Technol., 37, 22-31, 2003 b.

UNEP: Text of the Minamata Convention on Mercury for adoption by the Conference of Plenipotentiaries, unep.org. 31 July, 2013.

Wang, F., Saiz-Lopez, A., Mahajan, A. S., Gómez Martín, J. C., Armstrong, D., Lemes, M., Hay, T., and Prados-Roman, C.: Enhanced production of oxidised mercury over the tropical Pacific Ocean: a key missing oxidation pathway, Atmos. Chem. Phys., 14, 1323-1335, doi:10.5194/acp-14-1323-2014, 2014.

Whittlestone, S., Gras, J. L., and Siems, S. T.: Surface air mass origins during the first aerosol characterization experiment (ACE 1), J. Geophys. Res., 103, 16341-316350, 1998.
Williams, J., Gros, V., Bonsang, B., and Kazan, V.: HO cycle in 1997 and 1998 over the southern indian ocean derived from CO, radon, and hydrocarbon measurements made at Amsterdam island, J. Geophys. Res., 106, 12719-12725, 2001.

Witt, M. L. I., Mather, T. A., Baker, A. R., De Hoog, J. C. M., and Pyle, D. M.: Atmospheric trace metals over the south-west indian ocean: total gaseous mercury, aerosol trace metal concentrations and lead isotope ratios, Mar. Chem., 121, 2-16, 2010.

Yu, S., Mathur, R., Kang, D., Schere, K., and Tong, D.: A study of the ozone formation by ensemble back trajectory-process analysis using the Eta-CMAQ forecast model over the northeastern US during the 2004 ICARTT period, Atmos. Environ., 43, 355-363, 2009. 